\title{
Odorous Compounds from Poultry Manure Induce DNA Damage, Nuclear Changes, and Decrease Cell Membrane Integrity in Chicken Liver Hepatocellular Carcinoma Cells
}

\author{
Adriana Nowak ${ }^{1, *}(\mathbb{D})$, Tadeusz Bakuła ${ }^{2}$ (D), Katarzyna Matusiak ${ }^{1}$, Remigiusz Gałęcki ${ }^{3}$, \\ Sebastian Borowski ${ }^{1}$ and Beata Gutarowska ${ }^{1}$ \\ 1 Institute of Fermentation Technology and Microbiology, Lodz University of Technology, \\ Wolczanska 171/173, 90-924 Lodz, Poland; katarzyna.matusiak@p.lodz.pl (K.M.); \\ sebastian.borowski@p.lodz.pl (S.B.); beata.gutarowska@p.lodz.pl (B.G.) \\ 2 Department of Veterinary Prevention and Feed Hygiene, University of Warmia and Mazury in Olsztyn, \\ Oczapowskiego 13, 10-718 Olsztyn, Poland; bakta@uwm.edu.pl \\ 3 Faculty of Veterinary Medicine, University of Warmia and Mazury, ul. Oczapowskiego 13, \\ 10-719 Olsztyn, Poland; remigiusz.galecki@gmail.com \\ * Correspondence: adriana.nowak@p.lodz.pl; Tel.: +48-42-631-34-81
}

Received: 23 May 2017; Accepted: 14 August 2017; Published: 18 August 2017

\begin{abstract}
Animal breeding and management of organic wastes pose a serious problem to the health of livestock and workers, as well as the nearby residents. The aim of the present study was to determine the mechanisms of toxicity of selected common odorous compounds from poultry manure, including ammonia, dimethylamine (DMA), trimethylamine (TMA), butyric acid, phenol, and indole. We measured their genotoxic and cytotoxic activity in the model chicken cell line (LMH), in vitro, by comet assay and lactate dehydrogenase assay, respectively. We also made microscopic observations of any morphological changes in these cells by DAPI staining. Four compounds, namely ammonia, DMA, TMA, and butyric acid increased DNA damage in a dose-dependent manner $(p<0.05)$, reaching genotoxicity as high as $73.2 \pm 1.9 \%$. Phenol and indole induced extensive DNA damage independent of the concentration used. Ammonia, DMA, and TMA caused a dose-dependent release of lactate dehydrogenase $(p<0.05)$. The $\mathrm{IC}_{50}$ values were $0.02 \%, 0.05 \%$, and $0.1 \%$ for DMA, ammonia and TMA, respectively. These compounds also induced nuclear morphological changes, such as chromatin condensation, shrinkage, nuclear fragmentation (apoptotic bodies), and chromatin lysis. Our study exhibited the damaging effects of odorous compounds in chick LMH cell line.
\end{abstract}

Keywords: poultry odours; genotoxicity; cytotoxicity; DNA damage; comet assay; LDH assay; DAPI staining

\section{Introduction}

Air emission sources from animal production include buildings, animal feedlot surfaces, manure storage and treatment units, silage piles, and a variety of other smaller emission sources [1]. Emissions of odorous compounds from chicken sheds can lead to odour problems in the surrounding area, which lead to complaints from residents [2]. An unpleasant odour is associated with poultry manure, which results from a combination of up to 150 different compounds, including ammonia, amines, mercaptans, aldehydes, hydrogen sulphide, sulphur compounds, and esters [2-4]. The odours are mainly the products of the decomposition of chicken faeces, feathers, and litter by aerobic and anaerobic microorganisms. Each of these sources has a different emission profile, fluctuating during the day and throughout the year [1]. Thus, an effective odour removal technique is a great challenge 
for researchers. In our previous studies, we demonstrated that the treatment of poultry manure with mineral-microbial preparation successfully reduced odorants from feedstock. The odorants included ammonia, di- and trimethylamine, isobutyric acid, and other odorous compounds. We developed a novel microbial-mineral preparation composed of perlite and bentonite with spray-dried microorganisms, which was selected on the basis of active removal of odours from poultry manure $[5,6]$.

Ammonia, dimethylamine (DMA), trimethylamine (TMA), indole, phenol, and butyric acid are the most common compounds present in poultry manure [7-9]. Their health effects on humans and animals were discussed, in depth, in our previous study [10]. In summary, odorous compounds with long-term exposure can cause irritation of mucosal membranes in the respiratory tract in farm chickens, tracheal irritation, air sac inflammation, conjunctivitis, dyspnoea, respiratory tract damage, reddening, corneal clouding, reduction in respiratory rate, and central nervous system disturbances [10]. There is still insufficient in vitro data associated with the cyto- and genotoxicity of poultry odorous compounds with the application of cell lines. Thus far, we demonstrated the cytotoxicity of selected odorous compounds using the MTT (3-(4,5-dimethylthiazol-2-yl)-2,5-diphenyltetrazolium bromide) and PrestoBlue assays in the chicken Leghorn Male Hepatoma (LMH) cell line [10]. This helped us select appropriate concentrations of the odorous compounds for genotoxicity testing for this study. Here, we wanted to investigate the mechanisms of toxicity of selected odorous compounds, and examine if cytotoxicity is accompanied by genotoxicity, which can lead to mutations and cancer.

The aim of this study was to measure the genotoxicity (measurement of DNA damage using the comet assay) and cytotoxicity (necrosis in lactate dehydrogenase assay, along with $\mathrm{IC}_{50}$ values) of the most common odorous compounds from poultry manure in the chick LMH cell line, in vitro. In addition, we microscopically examined any morphological changes in the cellular nuclei (apoptosis or necrosis after fluorescent staining).

\section{Materials and Methods}

\subsection{Chemicals}

Ammonia, DMA, TMA, indole, phenol, and butyric acid were purchased from Sigma-Aldrich, St. Louis, MO, USA. The stocks were dissolved in Waymouth's Medium (Gibco, Thermo Fisher Scientific, Waltham, MA, USA) with no supplements and filter sterilized $(0.22 \mu \mathrm{M}$ pore size filter, Membrane Solutions, https://www.membrane-solutions.com/contact_us.htm). All compounds were freshly prepared on the day of the experiment.

\subsection{LMH Cell Culture}

The chick liver hepatocellular carcinoma cell line LMH (CLS, Germany, lot no. 601411-714SF), from the 24th passage, was used in our experiments as a model cell line. Aspiration of odorous compounds acts first on the respiratory tract, but many findings suggest, that they are then transported with blood to other organs, and to the liver, which takes part in their detoxification. The LMH cells were cultured as a monolayer as previously described [10]. Briefly, they were cultured in collagen-coated T75 flasks in Waymouth's Medium with 7.5\% sodium bicarbonate (Gibco, Thermo Fisher Scientific, Waltham, MA, USA), 10\% heat-inactivated foetal bovine serum (FBS) (Gibco, Thermo Fisher Scientific, Waltham, MA, USA), $25 \mathrm{mM}$ HEPES (Sigma-Aldrich, St. Louis, MO, USA), and antibiotics (100 IU/mL penicillin and $100 \mu \mathrm{g} / \mathrm{mL}$ streptomycin, Sigma-Aldrich, St. Louis, MO, USA). The cells were incubated in a $\mathrm{CO}_{2}$ incubator (Galaxy $48 \mathrm{~S}$, New Brunswick, United Kingdom) at $37^{\circ} \mathrm{C}$ in $5 \% \mathrm{CO}_{2}$ for 7 days to reach $80 \%$ confluence. The confluent cells were detached with TrypLE ${ }^{\mathrm{TM}}$ Express (Gibco, Thermo Fisher Scientific, Waltham, MA, USA) for 10 min at $37^{\circ} \mathrm{C}$, suspended in sterile PBS (Sigma-Aldrich, St. Louis, $\mathrm{MO}$, USA), aspirated off the plastic flask, centrifuged $(182 \times g, 5 \mathrm{~min})$, decanted, and re-suspended in fresh medium. The cells were ready to use if they had a minimum of $90 \%$ viability as tested by Trypan blue exclusion. 


\subsection{Comet Assay (SCGE-Single Cell Gel Electrophoresis Assay)}

The final concentration of LMH cells in each sample was adjusted to $10^{5}$ cells $/ \mathrm{mL}$. The cells in non-supplemented Waymouth's Medium were incubated with specific concentrations of each odorous compound at $37^{\circ} \mathrm{C}$ for $1 \mathrm{~h}$. The final series of concentrations of the odorous compounds in culture were: $0.001-0.006 \%$ for DMA and ammonia, $0.001-0.12 \%$ for TMA, $0.003-0.5 \%$ for butyric acid and indole, and $0.0004-0.1 \%$ for phenol. The concentrations were selected based on our previous studies, in which we determined the $\mathrm{IC}_{50}$ values of these odorous compounds by MTT and PrestoBlue assays, which were $0.02-0.08 \%$ for ammonia; $0.03-0.06 \%$ for DMA; $0.02-0.08 \%$ for TMA; $0.11-0.32 \%$ for butyric acid; and, $0.06 \%$ for indole, depending on the incubation time and the assay [10]. The comet assay was performed under alkaline conditions $(\mathrm{pH}>13)$, according to the procedure of Błasiak and Kowalik [11], as previously described [12]. In brief, after incubation, the cells were centrifuged $(182 \times g, 15 \mathrm{~min}$, $4{ }^{\circ} \mathrm{C}$ ), decanted, suspended in $0.75 \%$ low melting point (LMP) agarose, layered onto slides pre-coated with $0.5 \%$ normal melting point (NMP) agarose, and lysed at $4{ }^{\circ} \mathrm{C}$ for $1 \mathrm{~h}$ in a buffer consisting of $2.5 \mathrm{M} \mathrm{NaCl}, 1 \%$ Triton X-100, $100 \mathrm{mM}$ EDTA, and $10 \mathrm{mM}$ Tris, $\mathrm{pH} 10$. Next, the slides were placed in an electrophoresis unit, and DNA was allowed to unwind for $20 \mathrm{~min}$ in an electrophoretic solution consisting of $300 \mathrm{mM} \mathrm{NaOH}$ and $1 \mathrm{mM}$ EDTA. Electrophoresis was conducted at $4{ }^{\circ} \mathrm{C}$ for $20 \mathrm{~min}$ at an electric field strength of $0.73 \mathrm{~V} / \mathrm{cm}(300 \mathrm{~mA})$. Finally, the slides were neutralised in distilled water, stained with $2.5 \mu \mathrm{g} / \mathrm{mL}$ propidium iodide (PI) (Sigma-Aldrich, St. Louis, MO, USA), and covered with cover slips. The slides were observed at $200 \times$ magnification under a fluorescence microscope (Nikon Eclipse Ci H600L, Tokyo, Japan) connected to a video camera and a personal computer-based image analysis system, namely Lucia-Comet version 7.0 (Laboratory Imaging, Prague, Czech Republic). About 50 to 100 images were randomly selected from each sample and the percentage of DNA in the comet tail was measured.

\subsection{Lactate Dehydrogenase Activity (LDH) Assay}

The LDH cytotoxicity assay is based on the leakage of a cytoplasmic enzyme called lactate dehydrogenase from cells when the plasma membrane is damaged. This assay is useful to detect necrosis [13].

In our experiment, $1 \times 10^{4} \mathrm{LMH}$ cells, in a complete culture medium, were placed in each well of a 96-well plate coated with collagen (BioCoat, Becton, Dickinson and Co., Franklin Lakes, NJ, USA). The cells were incubated for $24 \mathrm{~h}$ at $37^{\circ} \mathrm{C}$ in $5 \% \mathrm{CO}_{2}$ to allow them to attach to the collagen-coated surface. The following day, the medium was aspirated and $200 \mu \mathrm{L}$ of each concentration of the test compound in Waymouth's Medium without FBS, was added to each well in eight repeats. The control samples consisted of cells without any test agent. The cells were incubated in a $\mathrm{CO}_{2}$ incubator at $37{ }^{\circ} \mathrm{C}$ in $5 \% \mathrm{CO}_{2}$ for $24 \mathrm{~h}$ in case of DMA, and $48 \mathrm{~h}$ in case of ammonia and TMA. The final test concentrations were: $0.004-1.0 \%$ for DMA and ammonia, and $0.004-1.0 \%$ for TMA. The concentrations investigated, and the times of incubation were chosen to detect $\mathrm{IC}_{50}$ values. In our previous studies [10], the viability of the cells was measured by MTT and PrestoBlue assays. In this study, only the three most cytotoxic odorous compounds were chosen, namely ammonia, DMA and TMA, to check for the mechanism of cell damage (loss in cell membrane integrity and probably

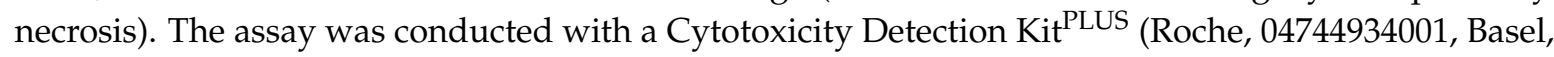
Switzerland), according to the manufacturer's instructions. Three controls were included: background control (assay medium), low control (untreated cells), and high control (maximum LDH release). To determine the experimental absorbance values, the average absorbance values of the 8-repeat samples and controls were calculated and subtracted from the absorbance values of the background control. The cytotoxicity was determined as follows: cytotoxicity $(\%)=((\exp$. Value-low control) $/($ high control-low control) $) \times 100$. The absorbance was detected at $490 \mathrm{~nm}$ with the use of a microplate reader (TriStar ${ }^{2}$ LB 942, Berthold Technologies GmbH and Co. KG, Bad Wildbad, Germany). Results were presented as mean \pm standard deviation (SD). The mean error of the method is up to $10 \%$. 


\subsection{Calculation of $I C_{50}$}

The values of $\mathrm{IC}_{50}$, which is the concentration of the test compound required to reduce the cell survival rate to $50 \%$ of the control, were used as a degree of cellular sensitivity to a given treatment. $\mathrm{IC}_{50}$ values were determined according to the formula: $\mathrm{IC}_{50}=(\mathrm{X}-\mathrm{Z}) /\left(\mathrm{X}-\mathrm{X}_{1}\right) \times\left(\mathrm{C}_{\mathrm{X} 1}-\mathrm{C}_{\mathrm{X}}\right)+\mathrm{C}_{\mathrm{X}}$, where $X$ is a $50 \%$ decrease in viability; $X$ is $\%$ of viability $>Z ; X_{1}$ is $\%$ viability $<Z ; C_{X}$ is concentration of the compound for $X$, and $C_{X 1}$ is concentration of the compound for $X_{1}[10,14]$.

\subsection{Fluorescence Microscopic Analysis}

The nuclear changes in LMH cells in the presence of test compounds were observed using 8-well Lab-Tek ${ }^{\mathrm{TM}}$ Chamber Slides (Nunc, Thermo Fisher Scientific, Waltham, MA, USA). Before culture, the slides were coated with collagen I (Gibco, Thermo Fisher Scientific, Waltham, MA, USA), according to the manufacturer's instructions. LMH cells were seeded on to each well at a concentration of $2.5 \times 10^{5}$ cells/well. In this experiment, three of the most cytotoxic odorous compounds were selected, which included ammonia, DMA, and TMA, to check for the mechanism of cell damage or apoptosis using DAPI (4',6-diamidino-2-phenylindole) staining. The final test concentrations were $0.03 \%$ for ammonia, DMA, and TMA, which were close to the $\mathrm{IC}_{50}$ values estimated in MTT assay after $48 \mathrm{~h}$ incubation [10].

After exposure to these compounds, the medium with compounds was removed, cells were washed with PBS (phosphate buffer saline) ( $\mathrm{pH} 7.2$ ) and fixed with $80 \%$ ethanol (for $20 \mathrm{~min}$ at room temperature). After air-drying, the cells were stained with $1 \mu \mathrm{g} / \mathrm{mL}$ DAPI in the dark. The morphology of cells was observed at 1000 × magnification under a fluorescent microscope (Nikon Eclipse Ci H600L, Tokyo, Japan), connected to a digital camera (Nikon Digital Sight DS-U3, Tokyo, Japan), and analysed using NIS-elements BR 3.0 imaging software (Nikon, Tokyo, Japan).

\subsection{Statistical Analysis}

Comet assay data were analysed using two-way analysis of variance (ANOVA), while a particular mode of interaction $\times$ time was used to compare the effects induced by the chemicals at this mode of interaction. Differences between samples with normal distribution were evaluated by Student's $t$-test. Both Student's $t$-test and ANOVA were performed using OriginPro 6.1 software (Northampton, MA, USA). Significant differences were accepted at $p<0.05$. The results were presented as mean \pm standard error of the mean (S.E.M.) (for the comet assays), and \pm standard deviation (SD) (for LDH).

\section{Results}

\subsection{DNA Damage in Chicken Liver Hepatocellular Carcinoma Cells}

Figure 1 displays the mean percentage of tail in the DNA of chicken hepatocytes that were exposed to odorous compounds and analysed by the alkaline comet assay. Representative images of control comets and actual sample after $0.03 \%$ DMA treatment, stained with propidium iodide are also shown (Figure 1).

Non-exposed cells (negative control) induced DNA damage of $5.0 \pm 0.8 \%$, while cell treatment with the positive control $\left(20 \mu \mathrm{M} \mathrm{H}_{2} \mathrm{O}_{2}\right)$ resulted in $42.6 \pm 4.2 \%$ DNA breakage.

Ammonia, DMA, TMA, and butyric acid increased tail DNA in a dose-dependent manner at all concentrations. Ammonia and DMA at $0.06 \%$ concentration were highly genotoxic inducing $64.9 \pm 5.6 \%$ and $64.0 \pm 3.9 \%$ DNA damage, respectively $(p<0.05) .0 .001 \%$ of ammonia, DMA, and TMA, induced mild and moderate genotoxicity in LMH cells of up to $13.3 \pm 1.6 \%, 10.5 \pm 1.6 \%$, and $8.3 \pm 2.9 \%$, respectively. Butyric acid induced extensive DNA damage at all concentrations, reaching $(73.2 \pm 1.9) \%$ at $0.5 \%$ concentration, and $(35.2 \pm 1.8) \%$ at $0.003 \%$ concentration. In contrast, phenol and indole highly increased tail DNA independent of the concentration. The genotoxicity of phenol and indole fluctuated from $(37.5 \pm 1.9) \%$ to $(57.1 \pm 2.2) \%$, and from $(37.3 \pm 1.8) \%$ to $(43.0 \pm 3.3) \%$, respectively. Simultaneously, phenol and indole induced very extensive DNA damage, 
so the results on the graph do not reflect the actual effects. Higher doses of both these compounds resulted in complete DNA fragmentation in many cells, what can be the result from cell death, but not true DNA damage. Also, the number of comets per slide was lower than that for the lower concentrations and in unexposed cells. This indicates a strong cytotoxicity of these compounds on the cells after 1-h exposure.
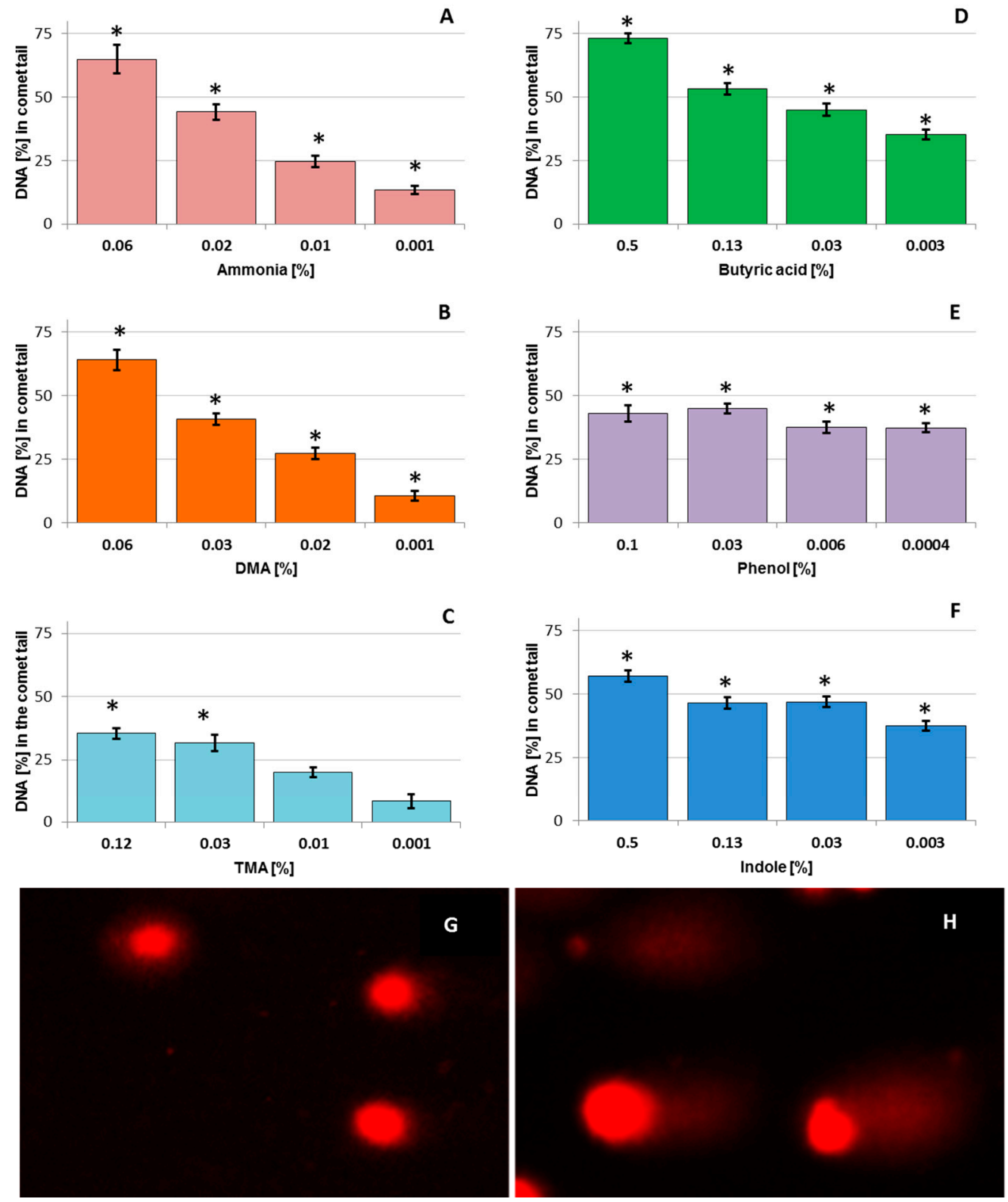

Figure 1. DNA damage in model chicken cell line (LMH) chicken cells after exposure to odorous compounds, such as (A) ammonia, (B) dimethylamine (DMA), (C) trimethylamine (TMA), (D) butyric acid, (E) indole and (F) phenol, expressed as the mean percentage of DNA in the comet tail in the alkaline comet assay. About 50 to 100 cells were analysed for each treatment. Data shown was obtained from two independent experiments. Error bars denote S.E.M. * Results were significantly different from unexposed control, ANOVA $(p<0.05)$. $\mathbf{G}$ and $\mathbf{H}$ show representative images of $2.5 \mu \mathrm{g} / \mathrm{mL}$ propidium iodide-stained comets: $(\mathbf{G})$ untreated control and $(\mathbf{H})$ sample exposed to $0.03 \%$ dimethylamine (extensive damage) in the alkaline comet assay. 


\subsection{Cytotoxicity and Determining $I C_{50}$}

We next investigated the mechanism by which odorous compounds can act on cells. Because butyric acid, phenol, and indole are formed in the farmhouses in low amounts [7-9], to the part of the research we chose the three main odorous compounds-ammonia, TMA, and DMA. We checked whether they affect cell membranes. One marker of membrane integrity is the level of the enzyme lactate dehydrogenase (LDH) that is released into the culture media. The LMH cells were challenged with the compounds for 24 or $48 \mathrm{~h}$ to observe the $\mathrm{IC}_{50}$ value, with concentrations ranging from $0.004 \%$ to $1.0 \%$ in eight repeats for each concentration.

All odorous compounds caused a dose-dependent release of LDH. Exposure to $0.031 \%$ concentration of ammonia showed a significant $(p<0.05)$ increase in cytotoxicity, which reached nearly $100 \%$ at concentrations of $0.25 \%, 0.5 \%$, and $1 \%$ (Figure 2 ). DMA had the highest cytotoxicity even in the presence of concentrations as low as $0.008 \%(42 \pm 0.1) \%$, indicating the disruption of the cell membrane structure. TMA appeared to be the least cytotoxic in the LDH assay, with the release in $\mathrm{LDH}$ reaching a maximum of $(58.6 \pm 0.04) \%$ at $1 \%$ concentration of TMA.

LMH cells treated with DMA resulted in high amounts of LDH release after only $24 \mathrm{~h}$, while those treated with ammonia and TMA took $48 \mathrm{~h}$; hence the different times of incubation. The $\mathrm{IC}_{50}$ of DMA was calculated after $24 \mathrm{~h}$ of exposure to be $0.02 \%$. For ammonia and TMA, IC 50 could be determined only after $48 \mathrm{~h}$ of exposure, and was found to be $0.05 \%$ and $0.1 \%$, respectively (Figure 2).

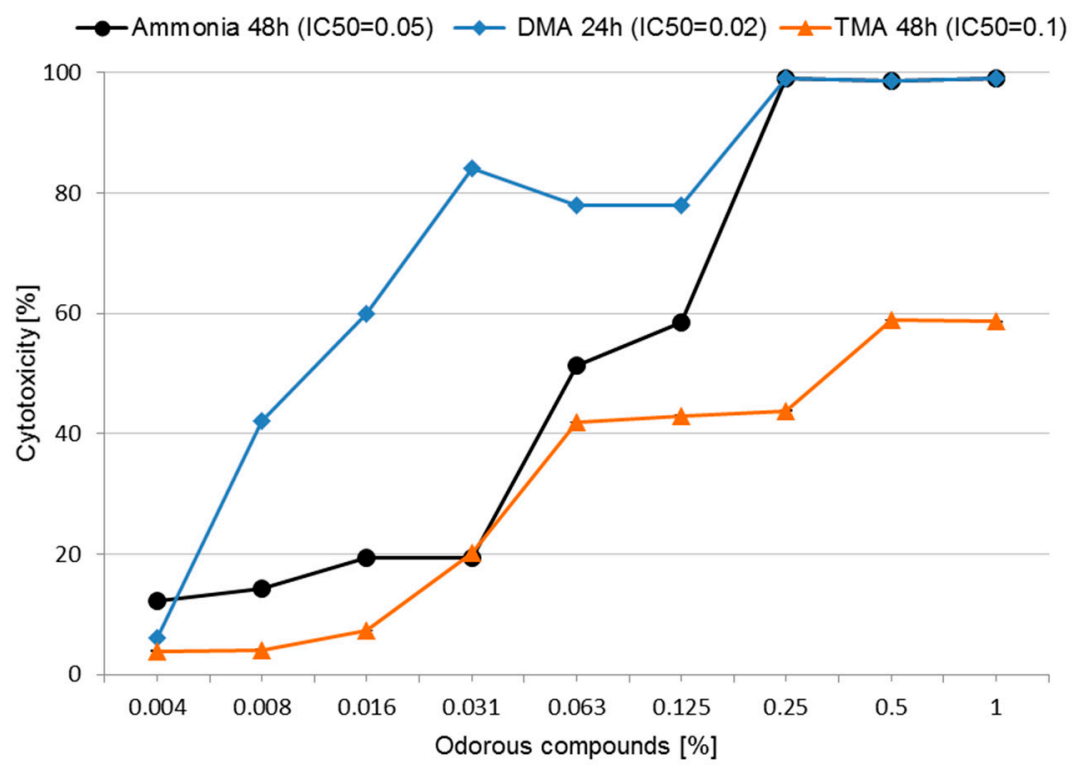

Figure 2. Cytotoxicity of ammonia, dimethylamine (DMA) and trimethylamine (TMA) in Lactate Dehydrogenase Activity (LDH) assay in LMH chicken cell line after $24 \mathrm{~h}$ (DMA) and $48 \mathrm{~h}$ (ammonia and TMA) exposure. Each data point represents the mean of the absorbance values of cells from eight individual wells $( \pm \mathrm{SD}) .{ }^{*} p<0.05$ for concentrations of ammonia, DMA and TMA as compared to unexposed controls.

\subsection{Nuclear Morphology of LMH Cells}

Morphological alterations in LMH chicken cells after exposure to odorous compounds were qualitatively investigated using a fluorescent microscope. In the presence of ammonia $(0.03 \%)$ (Figure 3A,C) chromatin condensation, cell shrinkage, as well as nuclear fragmentation (apoptotic bodies) were observed. Additionally, chromatin lysis and swelling of the cells were observed (Figure 3B), and this could possibly be due to necrosis. Chromatin condensation, shrinking of the cells, nuclear margination, and apoptotic bodies appeared after exposure to $0.03 \%$ DMA (Figure 3D,G) and TMA (Figure 3E,F). 


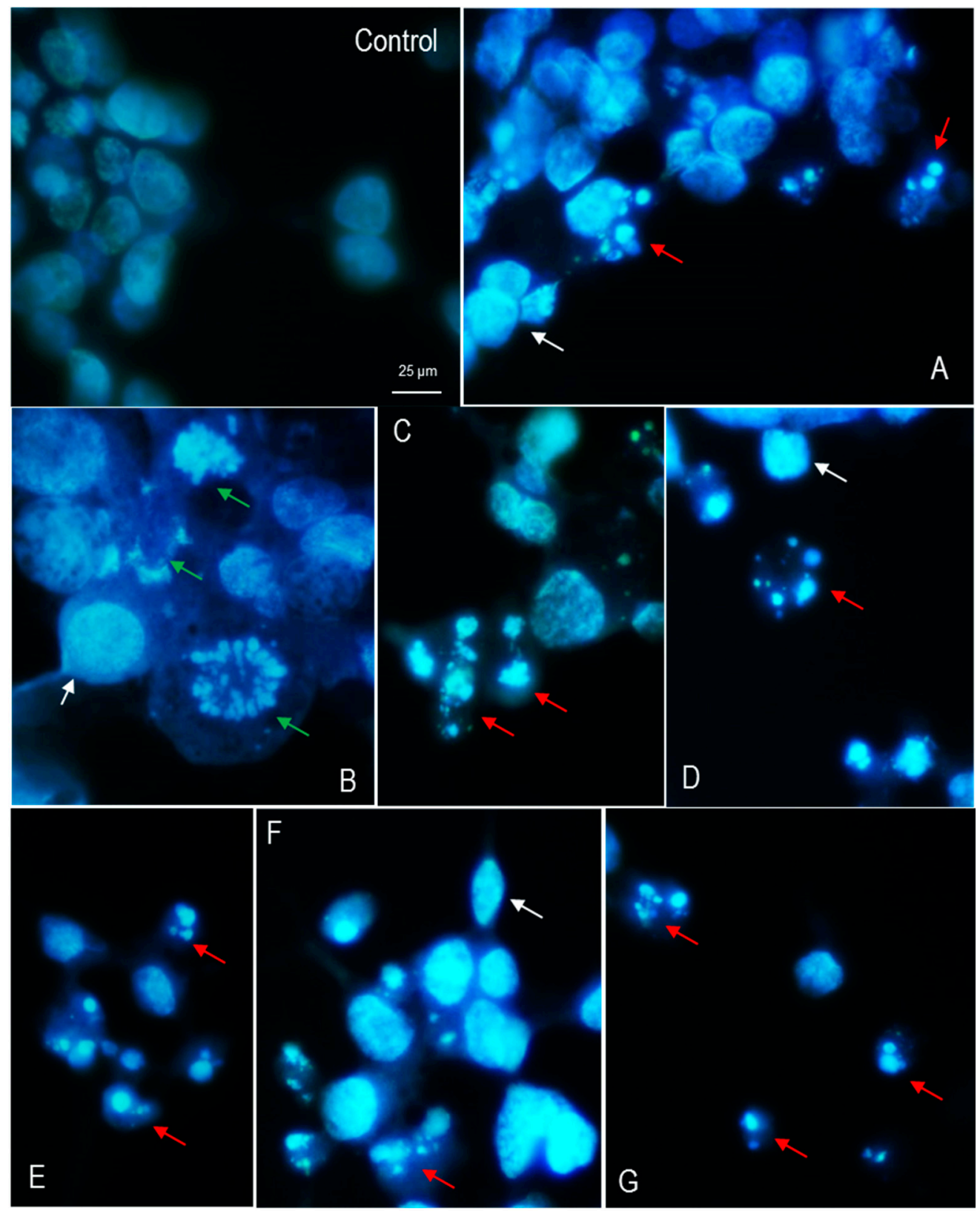

Figure 3. Nuclear morphology of LMH cells stained with DAPI (4' ${ }^{\prime}$,6-diamidino-2-phenylindole) after $48 \mathrm{~h}$ exposure to $0.03 \%$ ammonia $(\mathbf{A}-\mathbf{C})$, dimethylamine $(\mathbf{D}, \mathbf{G})$ and trimethylamine $(\mathbf{E}, \mathbf{F})$. Condensation of nuclear material (white arrows), apoptotic bodies (red arrows), cell swelling and chromatin lysis (green arrows) were observed. Fluorescence microscopy (Nikon, Tokyo, Japan); $1000 \times$ magnification. Images are representative of two independent experiments.

\section{Discussion}

Odorous compounds generated from chicken sheds are a potential nuisance to the environment and health of humans and animals. There are insufficient in vitro studies investigating geno- and cytotoxic mechanisms of poultry odorous compounds. We applied the comet assay to determine the mechanisms of action of the test odorous compounds. The assay is able to detect even low levels of DNA damage in a cell [15]. It can detect a wide range of DNA damage, such as single and double-strand breaks, base damage, inter-strand or DNA-protein cross-links, alkali labile sites, oxidised purines, and pyrimidines, as well as extensive DNA fragmentation [16]. The test concentrations should cover 
a range from the maximum acceptable cytotoxicity to little or no cytotoxicity, because DNA damage is associated with cell death [15]. In the current study, we selected concentrations based on our previous research, in which we investigated the cytotoxic activity of test odorous compounds using the MTT assay [10]. In the alkaline comet assay, all odorous compounds induced heavy damage to DNA in LMH cells. Butyric acid, phenol, and indole, triggered the most extensive genotoxic effects to the cells, as much as $35 \%$; in low concentrations, and for indole and phenol, it was also at a similar level. This is evidence of their high cytotoxicity to cells in suspension and inhibition of the DNA repair system (repair system has been overwhelmed by extensive damage). In contrast, ammonia, DMA, or TMA induced considerable damage to DNA of up to $64 \%$ at higher concentrations, and the results were comparable to the dose.

When treated with a toxic compound, living cells may stop growing and dividing, or die through necrosis or apoptosis. Generally, cells undergoing necrosis swell and loose membrane integrity, following which they shut down and release their intracellular contents into the extracellular area. In contrast, cells undergoing apoptosis are characterised by the shrinking of the cytoplasm, chromatin condensation, and DNA fragmentation [13]. Lactate dehydrogenase is an enzyme found inside every living cell. In LDH leakage assay, a tetrazolium salt is used in this test. When cell membrane integrity is compromised, the presence of this enzyme in the culture medium can be used as a cell death indicator. In the first stage, lactate dehydrogenase produces reduced NADH (nicotinamide adenine dinucleotide) when it catalyses the oxidation of lactate to pyruvate. In the second stage, a tetrazolium salt is converted to a coloured formazan using newly synthesized NADH in the presence of an electron acceptor. The amount of formazan can be quantified by standard spectroscopy. The assay enumerates the percentage of necrotic cells in a sample. Unfortunately, LDH release assay does not distinguish between primary necrosis and secondary necrosis as a consequence of apoptosis [13]. In the current research, the most cytotoxic compound in LDH assay was DMA, for which the $\mathrm{IC}_{50}$ $(0.02 \%)$ was estimated just after $24 \mathrm{~h}$ incubation. Ammonia also showed high cytotoxicity, but it was only possible to estimate $\mathrm{IC}_{50}$ after $48 \mathrm{~h}(0.05 \%)$. The least cytotoxic was TMA (IC 50 calculated after $48 \mathrm{~h}$ was $0.1 \%$ ). Similar results for ammonia, DMA, and TMA were achieved in our previous study [10] using the MTT (3-[4,5-dimethylthiazol-2-yl]-2,5-diphenyltetrazolium bromide) and PrestoBlue assays. These three compounds seem to be more toxic in the MTT assay. These differences highlight the differences in the mechanisms of cytotoxicity of these odorous compounds, and the different nature of each test. The LDH leakage assay is based on the release of the enzyme into the culture medium after cell membrane damage (cell death), while the MTT assay is based on the enzymatic conversion of MTT in the mitochondria. The formazan product is impermeable to the cell membranes, and therefore, it accumulates in healthy cells [17]. Thus, we can conclude, that the odorous compounds are destructive for mitochondria.

DAPI staining delivers a rapid and convenient assay for apoptosis based on fluorescent detection. DAPI is a specific DNA binding dye. This dye is not completely permeable, and normal cells give slight blue fluorescence with the round nucleus stained uniformly with its clear margins. Along with the apoptosis process, the ability of permeability improves, and the apoptotic cells produce high blue fluorescence, the margination of the nucleus is observed, and the condensation of chromatin is easily stained. Cell shrinkage, chromatin condensation, nuclear fragmentation, and nucleus margination are associated with the apoptotic mode of cell death. In our research, the cytotoxic effect of the test odorous compounds was supported by microscopic observations of nuclear morphological changes. Cells incubated for $48 \mathrm{~h}$ with $0.03 \%$ ammonia presented nuclei with either apoptotic (apoptotic bodies), or necrotic morphology, with nucleus fragmentation of different sizes. Some nuclei appeared to be dispersed within the cytoplasm, and cell swelling was observed. Apoptotic symptoms dominated after treatment with $0.03 \%$ DMA or TMA. In our previous study [10], by using Giemsa/May-Grünwald staining we demonstrated that the treatment of $\mathrm{LMH}$ cells with these compounds produced inter alia chromatin condensation and fragmentation. The $\mathrm{IC}_{50}$ doses of test odorous compounds changed 
nuclear morphology and induced apoptosis in LMH cells, but the data requires confirmation by other tests.

Genotoxic activity of ammonia was documented by several researchers. In this paper, using the comet assay we found that, depending on the concentration, ammonia induced extensive DNA damage in chicken cells. In contrast, Yadav and Kaushik [18] found that ammonia induced micronuclei formation in Swiss albino mice, and inhibited DNA repair in mouse fibroblasts. One study examined the genotoxic effect of ammonia in humans [18]. Analysis of blood samples, from 22 individuals exposed to ammonia (working in a fertilizer factory), and 42 control individuals not exposed to ammonia, showed increased frequency of chromosomal aberrations, sister chromatid exchanges, and an increased mitotic index in blood samples of exposed individuals. The frequency of DNA damage increased along with the increasing length of exposure. In our research, geno- and cytotoxic activity of ammonia could occur as a result of alkalisation. But Mouille et al. [19] demonstrated that ammonia acts on colon HT-29 cells as an antimitotic agent, independent of the $\mathrm{pH}$. We showed that ammonia changes the morphology of the nuclei in LMH chicken cells. Mouille et al. [19], using in vivo animal experiments with ammonia, showed that excessive amounts of odorous compounds alter colonic epithelial cell morphology and increase cell proliferation. Contrary to our findings, the authors established that ammonia $\left(20 \mathrm{mM} \mathrm{NH}_{4} \mathrm{Cl}\right)$ did not significantly affect the viability of human colon HT-29 cells by decreasing the integrity of the cell membrane (LDH release). Our findings support geno- and cytotoxic action of ammonia, what was proved by other researches, with the application of another or the same methods, but different models of the cell lines. Pan et al. [20] examined the toxicity of ammonia present in urea and chicken manure, on plant roots, including wheat, canola, and faba, which developed expanded toxicity zones initiated at the root apex. The authors observed progressive necrosis and shrinking of the root axis and root hairs. Ammonia sources also caused inhibition of root elongation within 4 to $8 \mathrm{~h}$ of exposure. Gupta et al. [21] observed the toxic effects of poultry litter aqueous leachate in Ceriodaphnia dubia, and the main constituents of the leachate was ammonia and anionic organic compounds. Toxicity of water elutriates of chicken manure in protozoa, such as Paramecium caudatum, as well as the crustacean Daphnia magna, as test objects was demonstrated by Galitskaya and Selivanovskaya [22]. Delgado et al. [23] showed phytotoxicity of poultry manure in a study using the cress. Poultry litter leachate was found to be mutagenic to Salmonella Typhimurium strains TA 97, TA 98, TA 100, and TA 102 using the Ames test [24]. It is necessary to mention that ammonia accumulates as a result of glutamine metabolism, and is a toxic by-product of animal cell culture [25,26]. It can exhibit such negative effects as inhibition of cell growth, protein production and glycosylation [26]. Following DAPI staining of LMH cells after exposure to ammonia, characteristic apoptosis symptoms were observed. Mirabet et al. [27] demonstrated that ammonia can induce cell death due to apoptosis, and that the toxic effects caused by ammonia are different depending upon the cell line type.

In the comet assay we showed that DMA and TMA increased DNA damage in a dose-dependent manner. Genotoxic activity of DMA was studied in Saccharomyces cerevisiae D7 and evaluated by Galli et al. [28]. DMA induced conversion of gene and point reverse mutation after metabolic activation. It also showed hepatotoxic effect by a significant reduction in the activity of selected monooxygenase enzymes. Pool et al. [29] showed that DMA induced single-strand DNA breaks in hepatocytes of rats, hamsters, and pigs using a 1 or 3-h culture suspension technique. The breaks were seen in liver cells after treatment with $1 \mathrm{mg} / \mathrm{kg}$ DMA, and in kidney and lung cells at a dosage of $20 \mathrm{mg} / \mathrm{kg}$ DMA [30]. TMA appeared to be genotoxic/mutagenic in Ames test with Salmonella Typhimurium [31]. It also induced chromosomal aberrations without metabolic activation in the Chinese hamster cell line [32,33]. The authors proposed that the mechanism of its action was a shift in $\mathrm{pH}$. In our study, the test samples were not neutralized. Therefore; the mechanism of their geno- and cytotoxic action may have been related to a $\mathrm{pH}$ shift.

We demonstrated that phenol and indole induced strong DNA damage, independent of the concentration. Phenol was assessed as a genotoxin by Li et al. [34]. The authors showed that 
phenol caused a significant increase in micronucleus frequencies when compared to the solvent control. It also induced statistically significant increases in DNA damage (in comet assay) on three different biomaterials (i.e., lymphocyte of human, spermatid of mouse, and akaryocyte of crucian). Phenol appeared to be mutagenic in vitro in Vicia faba and mouse spleen cells (sister chromatid exchange) [35], induced DNA oxidative damage in human promyelocytic HL-60, and mouse bone-marrow cells [36]. Phenol also induced sister chromatid exchange in human lymphocytes [37,38]. It also showed genotoxicity in a micronucleus test in mouse bone-marrow cells $[39,40]$. Indole and its derivatives are derived from bacterial degradation of tryptophan, and contributes to the characteristic odour of faeces. Reddy et al. [41] evaluated the genotoxic potential of indole derivatives (3-methylindole, melatonin, serotonin, and tryptamine) in vitro. All compounds produced DNA adducts in calf thymus DNA in the presence of rat liver S9. In cultured rat hepatocytes, all produced DNA adducts. In our research, butyric acid induced extensive DNA damage. The ability of butyric acid to inhibit cell growth, followed by the increase in apoptosis in Jurkat human $\mathrm{T}$ lymphocytes was described by Kurita-Ochiai et al. [42]. The authors indicated that butyric acid has bimodal effects on cell proliferation and survival. The apoptosis was induced by high levels of butyric acid. Several other studies have also demonstrated the ability of butyric acid to induce apoptosis in different cell lines in vitro [43-45].

In our study, low concentrations of ammonia and TMA showed little or no cytotoxicity in the $\mathrm{LDH}$ assay, but were found to be highly genotoxic in the comet assay. The same effect as in the LDH assay was observed for all tested odorous compounds in the MTT assay (in our previous study) [10]. It arises from the fact that a cytotoxic agent may be genotoxic (cause damage to DNA), or may be destructive for cell organelles (e.g., cell membrane or mitochondria), but not each cytotoxic chemical must induce genotoxicity. Furthermore, genotoxic substances may induce DNA damage at non-cytotoxic concentrations. Genotoxicity, may lead to cancer-causing mutations, but it does not have to be cytotoxic for the cell. From our research we can conclude, that ammonia, DMA, and TMA are very harmful to LMH cells, probably because of some similarities in their chemical structures, and hence cellular interactions leading to downstream toxicity.

\section{Conclusions}

Our findings suggest, that odorous compounds can be cyto- and genotoxic in vitro, hence they are also likely to be harmful in vivo. Ammonia, DMA, TMA, phenol, indole, and butyric acid have extensive geno- and cytotoxicity, which could be caused by changes in the $\mathrm{pH}$ of the medium. Ammonia, DMA and TMA induce cytotoxicity in LMH chicken cell line by loss in cell membrane integrity and, probably, necrosis. They also change the nuclear morphology of LMH cells, causing chromatin condensation and fragmentation, and also cause an increase in apoptotic bodies, as observed with DAPI staining. Thus, these compounds can induce cell death in two ways: necrosis and apoptosis, but the findings need to be confirmed using additional in vitro studies involving tests for detecting apoptosis. Finally, our research demonstrates that the comet and LDH assays, as well as DAPI staining, are appropriate and sensitive methods to screen selected odorous compounds for genoand cytotoxicity testing.

Acknowledgments: The study was funded by the Centre for Research and Development, Poland (Grant title "Innovative deodorising biopreparation for poultry farmhouses"; grant number PBS2/B8/14/2014).

Author Contributions: Adriana Nowak conceived, designed and performed the experiments, analysed the data and wrote the paper; Katarzyna Matusiak and Sebastian Borowski corrected the manuscript; Tadeusz Bakuła and Remigiusz Gałecki analysed the data; Beata Gutarowska initiated the research concept and corrected the manuscript.

Conflicts of Interest: The authors declare no conflict of interest. 


\section{References}

1. Jacobson, L.D.; Bicudo, J.R.; Schmidt, D.R.; Wood-Gay, S.; Gates, R.S.; Hoff, S.J. Air Emissions from Animal Production Buildings. Available online: http:/ /www.isah-soc.org/userfiles/downloads/proceedings/2003/ mainspeakers/18JacobsonUSA.pdf (accessed on 10 April 2017).

2. Dunlop, M.W.; Blackall, P.J.; Stuetz, R.M. Odour emissions from poultry litter-A review litter properties, odour formation and odorant emissions from porous materials. J. Environ. Manag. 2016, 177, 306-319. [CrossRef] [PubMed]

3. Li, H.; Xin, H.; Burns, R.T.; Jacobson, L.D.; Noll, S.; Hoff, S.J.; Harmon, J.D.; Koziel, J.A.; Hetchler, I. Air Emissions from Tom and Hen Turkey Houses in the U.S. Midwest. Available online: http:/ /www.abe.iastate. edu/adl/files/2011/10/Turkey-Emissions1.pdf (accessed on 24 April 2017).

4. Rabadheera, C.S.; Mcconchie, R.M.; Phan-Thien, K.; Bell, T. Strategies for eliminating chicken odour in horticultural applications. World Poult. Sci. J. 2017, 73, 365-378. [CrossRef]

5. Gutarowska, B.; Borowski, S.; Durka, K.; Korczyński, M.; Kołacz, R. Screening of microorganisms capable to remove odorous compounds from poultry manure. Przem. Chem. 2009, 88, 440-445.

6. Borowski, S.; Matusiak, K.; Powałowski, S.; Pielech-Przybylska, K.; Makowski, K.; Nowak, A.; Rosowski, M.; Komorowski, P.; Gutarowska, B. A novel microbial-mineral preparation for the removal of offensive odors from poultry manure. Int. Biodeter. Biodeg. 2017, 119, 299-308. [CrossRef]

7. McGahan, E. Strategies to reduce odour emissions from meat chicken farms. Proc. Poult. Inf. Exch. 2002, 27-39. Available online: http:/ / citeseerx.ist.psu.edu/viewdoc/download?doi=10.1.1.582.29\&rep=rep1\&type=pdf (accessed on 3 April 2017).

8. Dinh, H.H.T. Analysis of Ammonia and Volatile Organic Amine Emissions in a Confined Poultry Facility. Available online: http:/ / digitalcommons.usu.edu/etd/598/ (accessed on 3 April 2017).

9. Gutarowska, B.; Matusiak, K.; Borowski, S.; Rajkowska, A.; Brycki, B. Removal of odorous compounds from poultry manure by microorganisms on perlite-bentonite carrier. J. Environ. Manag. 2014, 141, 70-76. [CrossRef] [PubMed]

10. Nowak, A.; Matusiak, K.; Borowski, S.; Bakuła, T.; Opaliński, S.; Kołacz, R.; Gutarowska, B. Cytotoxicity of odorous compounds from poultry manure. Int. J. Environ. Res. Public Health 2016, 13, 1046. [CrossRef] [PubMed]

11. Błasiak, J.; Kowalik, J. A comparison of the in vitro genotoxicity of tri- and hexavalent chromium. Mutat. Res. 2000, 469, 135-145. [CrossRef]

12. Nowak, A.; Śliżewska, K. $\beta$-Glucuronidase and $\beta$-glucosidase activity and human fecal water genotoxicity in the presence of probiotic lactobacilli and the heterocyclic aromatic amine IQ in vitro. Environ. Toxicol. Pharmacol. 2014, 37, 66-73. [CrossRef] [PubMed]

13. Chan, F.K.; Moriwaki, K.; De Rosa, M.J. Detection of necrosis by release of lactate dehydrogenase (LDH) activity methods. Mol. Biol. 2013, 979, 65-70.

14. OECD Guidelines for the Testing of Chemicals, Section 4. Test No. 442D: In Vitro Skin Sensitisation are-nrf2 Luciferase Test Method. Available online: https://ntp.niehs.nih.gov/iccvam/suppdocs/feddocs/oecd/ oecd-tg442d-508.pdf (accessed on 20 March 2017).

15. Tice, R.R.; Agurell, E.; Anderson, D.; Burlinson, B.; Hartmann, A.; Kobayashi, H.; Miymae, Y.; Rojas, E.; Ryu, J.-C.; Sasaki, Y.F. Single cell gel/comet assay: Guidelines for in vitro and in vivo genetic toxicology testing. Environ. Mol. Mutagen. 2000, 35, 206-221. [CrossRef]

16. Collins, A.R. The comet assay for DNA damage and repair. Mol. Biotechnol. 2004, 26, 249-261. [CrossRef]

17. Fotakis, G.; Timbrell, J.A. In vitro cytotoxicity assays: Comparison of LDH, neutral red, MTT and protein assay in hepatoma cell lines following exposure to cadmium chloride. Toxicol. Lett. 2006, 160, 171-177. [CrossRef] [PubMed]

18. Yadav, J.S.; Kaushik, V.K. Genotoxic effect of ammonia exposure on workers in a fertility factory. Indian J. Exp. Biol. 1997, 35, 487-4920. [PubMed]

19. Mouillé, B.; Delpal, S.; Mayeur, C.; Blachier, F. Inhibition of human colon carcinoma cell growth by ammonia: A non-cytotoxic process associated with polyamine synthesis reduction. Biochim. Biophys. Acta 2003, 1624, 88-97. [CrossRef] [PubMed]

20. Pan, W.L.; Madsen, I.J.; Bolton, R.P.; Graves, L.; Sistrunk, T. Ammonia/ammonium toxicity root symptoms induced by inorganic and organic fertilizers and placement. Agron. J. 2016, 108, 2485-2492. [CrossRef] 
21. Gupta, G.; Borowiec, J.; Okoh, J. Toxicity identification of poultry litter aqueous leachate. Poult. Sci. 1997, 76, 1364-1367. [CrossRef] [PubMed]

22. Galitskaya, P.; Selivanovskaya, S. Co-composting as a method to decrease toxicity of chicken manure. Int. J. Adv. Biotechnol. Res. 2016, 7, 1276-1282.

23. Delgado, M.; Martin, J.V.; De Imperial, R.M.; León-Cófreces, C.; Cruz García, M. Phytotoxicity of uncomposted and composted poultry manure. Afr. J. Plant Sci. 2010, 4, 154-162.

24. Gupta, G.; Kelly, P. Poultry litter toxicity comparison from various bioassays. J. Environ. Sci. Health. Part A Environ. Sci. Eng. Toxicol. 1992, 27, 1083-1093. [CrossRef]

25. Slivac, I.; Blajić, V.; Radošević, K.; Kniewald, Z.; Gaurina Srček, V. Influence of different ammonium, lactate and glutamine concentrations on CCO cell growth. Cytotechnology 2010, 62, 585-594. [CrossRef] [PubMed]

26. Tae, K.-H.; Lee, G.M. Glutamine substitution: The role it can play to enhance therapeutic protein production. Pharm. Bioprocess. 2015, 3, 249-261.

27. Mirabet, M.; Navarro, A.; Lopez, A.; Canela, E.I.; Mallol, J.; Lluis, C.; Franco, R. Ammonium toxicity in different cell lines. Biotechnol. Bioeng. 1997, 56, 530-537. [CrossRef]

28. Galli, A.; Paolini, M.; Lattanzi, G.; Cantelli-Forti, G.; Bronzetti, G. Genotoxic and biochemical effects of dimethylamine. Mutagenesis 1993, 8, 175-178. [CrossRef] [PubMed]

29. Pool, B.L.; Brendler, S.Y.; Liegibel, U.M.; Tompa, A.; Schmezer, P. Employment of adult mammalian primary in toxicology: In vivo and in vitro genotoxic effects of environmentally significant $N$-nitrosodialkylamines in cells of the liver, lung, and kidney. Environ. Molec. Mutagen. 1990, 15, 24-35. [CrossRef]

30. United States Environmental Protection Agency, Acute Exposure Guideline Levels (AEGLs) for Dimethylamine. Available online: https: / www.epa.gov/sites/production/files/2014-08/documents/dimethylamine_tsd_ interim_version_106_2008.pdf (accessed on 4 April 2017).

31. Mortelmans, K.; Haworth, S.; Lawlor, T.; Speck, W.; Tainer, B.; Zeiger, E. Salmonella mutagenicity tests. 2. Results from the testing of 270 chemicals. Environ. Mutagen. 1986, 8, 1-119. [CrossRef] [PubMed]

32. MHLW (Japanese Ministry of Health, Labour and Welfare). Trimethylamine; MHLW: Tokyo, Japan, 2003.

33. MHLW (Japanese Ministry of Health, Labour and Welfare). In Vitro Chromosomal Aberration Test of Trimethylamine on Cultured Chinese Hamster Cells; MHLW: Tokyo, Japan, 2003.

34. Li, Y.; Qu, M.; Sun, L.; Wu, Y.; Chen, Y.; Chen, H.; Kong, Z.; Liu, Z. Genotoxicity study of phenol and o-cresol using the micronucleus test and the comet assay. Toxicol. Environ. Chem. 2005, 87, 365-372. [CrossRef]

35. Zhang, Z.; Yang, J.; Zhang, Q.; Cao, X. Studies on the utilization of a plant SCE test in detecting potential mutagenic agents. Mutat. Res. 1991, 261, 69-73. [CrossRef]

36. Kolachana, P.; Subrahmanyam, V.V.; Meyer, K.B.; Zhang, L.; Smith, M.T. Benzene and its phenolic metabolites produce oxidative damage in HL60 cells in vitro and in the bone marrow in vivo. Cancer Res. 1993, 53, 1023-1026. [PubMed]

37. Morimoto, K.; Wolff, S.; Koizumi, A. Induction of sister-chromatid exchanges in human lymphocytes by microsomal activation of benzene metabolites. Mutat. Res. 1983, 119, 355-360. [CrossRef]

38. Erexson, G.L.; Wilmer, J.L.; Kligerman, A.D. Sister chromatid exchanges induction in human lymphocytes exposed to benzene and its metabolites in vitro. Cancer Res. 1985, 45, 2471-2477. [PubMed]

39. Ciranni, R.; Barale, R.; Marrazzini, A.; Loprieno, N. Benzene and the genotoxicity of its metabolites: I. Transplacental activity in mouse fetuses and in their dams. Mutat. Res. 1988, 208, 61-67. [CrossRef]

40. Chen, H.; Eastmond, D.A. Synergistic increase in chromosomal breakage within the euchromatin induced by an interaction of the benzene metabolites phenol and hydroquinone on mice. Carcinogenesis 1995, 16, 1963-1969. [CrossRef] [PubMed]

41. Reddy, M.V.; Storer, R.D.; Laws, G.M.; Armstrong, M.J.; Barnum, J.E.; Gara, J.P.; McKnight, C.G.; Skopek, T.R.; Sina, J.F.; DeLuca, J.G.; et al. Genotoxicity of naturally occurring indole compounds: Correlation between covalent DNA binding and other genotoxicity tests. Environ. Mol. Mutagen. 2002, 40, 1-17. [CrossRef] [PubMed]

42. Kurita-Ochiai, T.; Hashizume, T.; Yonezawa, H.; Ochiai, K.; Yamamoto, M. Characterization of the effects of butyric acid on cell proliferation, cell cycle distribution and apoptosis. FEMS Immunol. Med. Microbiol. 2006, 47, 67-74. [CrossRef] [PubMed]

43. Watkins, S.M.; Carter, L.C.; Mak, J.; Tsau, J.; Yamamoto, S.; German, J.B. Butyric acid and tributyrin induce apoptosis in human hepatic tumour cells. J. Dairy Res. 1999, 66, 559-567. [CrossRef] [PubMed] 
44. Kurita-Ochiai, T.; Ochiai, K.; Fukushima, K. Butyric Acid-induced T-cell apoptosis is mediated by caspase-8 and -9 activation in a fas-independent manner. Clin. Diagn. Lab. Immunol. 2001, 8, 325-332. [CrossRef] [PubMed]

45. Kurita-Ochiai, T.; Seto, S.; Suzuki, N.; Yamamoto, M.; Otsuka, K.; Abe, K.; Ochiai, K. Butyric acid induces apoptosis in inflamed fibroblasts. J. Dent. Res. 2008, 87, 51-55. [CrossRef] [PubMed] 